\title{
Materiality, Authority, and Digital Religion The Case of a Neo-Pagan Forum
}

\author{
GIULIA EVOLVI \\ Department of Media and Communication, Erasmus University Rotterdam
}

\begin{abstract}
The study of material culture increasingly pays attention to digital religion, but there are certain aspects, such as religious authority, that remain under-researched. Some questions are still open for inquiry: What can a material approach contribute to the understanding of religious authority in digital venues? How can authority be materially displayed on the Internet? This article shows how religious authority is affected by material practices connected with digital media use through the qualitative analysis of a Neo-Pagan forum, The Celtic Connection. Neo-Pagans tend to hold a non-traditional notion of authority, accord great importance to material practices, and extensively use the Internet. The analysis of the forum suggests that Neo-Pagans use digital venues to look for informal sources of authority and strategies to embed materiality in online narratives. The article claims that it is important to develop new frameworks to analyze non-traditional authority figures and new definitions of media that include both physical objects and communication technologies.
\end{abstract}

KEYWORDS digital culture, digital religion, Neo-Paganism, Wicca, authority, materiality, media, Internet

\section{Introduction}

Religious practices are embedded in people's everyday lives and manifest in a variety of tangible forms. It is for this reason that scholars increasingly pay attention to material culture in relation to religion. Material culture participates in what Birgit Meyer (2010) defines as "mediation," where a "medium" is an object charged with religious meanings that helps believers to bridge the distance between immanence and transcendence. For instance, writes Meyer, a Catholic icon may be carved from wood by a person, but it is considered as the embodiment of a sacred presence by believers who touch or kiss it (2010,13, see also 2020). Mediation is not limited to images but includes a large array of material objects, such as artworks, books, television, the Internet, as well as embodied practices, multisensorial experiences, and religious spaces (Morgan 2016). 
A material approach to the study of religion compels the study of media technologies as part of material culture. Media, and especially the Internet, might be considered as "intangible" and disconnected from materiality. The notion of "virtual" is often employed, indeed, to describe exchanges that do not involve material objects and physical encounters between people. However, many scholars agree that the Internet does embed materiality in various ways and can activate practices that involve embodied and sensorial experiences (Houtman and Meyer 2012). For example, in studying Pentecostalism in Ghana, Meyer (2005) explores the use of mass media in church services, which participate in mediation by making believers materially approach the religious experience. In the late 1990s, Meyer writes, a number of Charismatic Churches produced recordings of sermons and even performances of miracles, something that confirmed and increased the authority of the pastor by providing people with a tangible testimony of spiritual power $(2005,440)$. Material aspects in religious mediation persist, and are enhanced, in the Internet age. Tim Hutchings and McKenzie (2016), for instance, argues that digital software also functions as material objects. Hutchings explores, among other examples, Bible apps that visually mimic printed books and paper Bibles with QR codes that connect to online resources. In both cases, materiality is taken into account and embedded into digital practices, and both "virtual" and "tangible" characteristics coexist.

Despite the importance of materiality within Internet practices, the existing literature on material culture and digital religion still needs to thoroughly address some questions. Hutchings and McKenzie (2016) notes that while scholars generally agree that the study of material culture should pay attention to digital media, they seldom provide precise definitions of material aspects embedded in Internet practices. This paper focuses on religious authority as one such aspect, which is often dependent on material objects (e.g. texts and religious spaces) but is usually not explored in relation to materiality in literature about digital venues. Some questions are, indeed, still open for inquiry: How can a material approach add complexity to the study of digital religion? What can this approach contribute to the understanding of religious authority in digital venues? How can authority be materially displayed on the Internet? A material culture perspective can help to understand some facets of "digital religion," a term Heidi Campbell (2012a, 2012b) employs to describe a type of religion that is influenced by digital culture. This article presents the case study of a Neo-Pagan forum to illustrate how material culture participates in the negotiation of authority in digital venues.

The following sections explore religious authority in relation to media, with particular attention to the Internet. The article proceeds by describing Neo-Paganism, a new religious movement that often relies on non-institutional forms of authority and Internet-mediated communications. The analysis of "The Celtic Connection" (www.wicca.com), a Neo-Pagan forum, provides examples of how religious authority is negotiated and materially displayed online. In conclusion, the article presents reflections on how to develop new frameworks to analyze non-traditional authority figures and definitions of media that include both physical objects and communication technologies.

\section{Discussing Authority, Media, and Religion}

The question of authority is central to many academic inquiries on religion. When discussing religious authority, scholars often refer to Max Weber's ([1921-1922] 2013) categories of legal, traditional, and charismatic authority. From this perspective, authority is not solely a form of domination, but also a system of legitimation gained through social performance 
and symbolic construction. It depends on power dynamics that support a dominant worldview within the particular religion (Horsfield 2016). According to Stewart Hoover (2016), media create new venues for religion to become public and visible, also in material terms. Media are involved in legitimating authority because they can, in certain circumstances, confer authenticity and plausibility to a given person or institution by producing, distributing, and shaping information. For example, the Pope's Twitter account constitutes a strategy to enhance Catholic leadership among certain audiences and to reinforce a specific system of power legitimation (Narbona 2016).

While media have historically always participated in the legitimation of religious authority (Horsfield 2013), the diffusion of communication technologies compels new theoretical efforts to understand authority in contemporary settings. The abundance of information in online environments, indeed, makes it more challenging for users to recognize trustworthy and credible sources of information (Metzger and Flanagin 2013). Stewart Hoover (2016) argues that media can produce alternative forms of authority because believers can find new perspectives on traditional power hierarchies in the media and negotiate religious meanings without the guidance of a recognized authority. As a result, some traditional religious institutions lose control of religious symbols and truth claims. Religious leaders may no longer retain exclusivity on religious interpretation because as mass-mediated conversations are increasingly more public, they need to defend their claims in the public sphere rather than in private settings. Therefore, Hoover proposes that the media age affects Weber's three categories of authority to different extents, and claims that leaders who emerge on media platforms tend to hold charismatic and traditional authority rather than legal authority.

The diffusion of the Internet further impacts religious authority. This happens because, as Campbell (2007, 2010) writes, digital religion becomes "networked," meaning that aspects of religion such as authority increasingly depend on new modes of interaction and connections between users and narratives. On the one hand, the Internet can reinforce existing authorities when traditional religious institutions are able to use digital venues to establish new channels of communication. On the other hand, digital culture may disrupt traditional authority by creating new forms of leadership based on online visibility and digital expertise. For example, as for the work of Hanna Staehle in the Russian context (2018, 2020), the Moscow Patriarchate needs to understand new media logics facing the rise of alternative authority figures that extensively use social networks and might disrupt traditional structures of authority. With regard to Weber's categories, the Internet offers a space for the display of traditional authority, while at the same time facilitating the emergence of charismatic leaders. This does not mean that offline authority connected to religious institutions disappears, but that religious authority becomes more fluid and nuanced. As Heidi Campbell and Mia Lövheim write,

[C] urrent research shows that the issue is not so much a shift from 'old' to 'new' forms of authority, but rather, the integration and reconstruction of existing ones in which some relations of power remain and some are reconstructed. In this process, we also see how recognizing the importance of online literacy and leveraging of connection resource become crucial for offline religious leaders and communities. $(2011,1089)$

The quote suggests that the study of digital religion needs to consider power relations between established authorities and new forms of Internet-based hierarchies. While Weber's distinction of institutional, traditional, and charismatic authority may remain valid in some 
circumstances, it is also important to keep in mind that new roles emerge outside traditional institutions. I agree with Hoover that academics need to think about religion, media, and authority in new ways $(2016,4)$. In this regard, I would argue that religious authority in a networked society, while remaining a system of legitimation that includes human and nonhuman sources, can be better understood from a material perspective. By discussing the case of the Neo-Pagan forum The Celtic Connection, this article shows how religious authority is not only affected by the logics of media but also by the material practices connected with media use.

\section{Neo-Pagan Authority and Online Practices}

The term Neo-Paganism refers to a variety of spiritual and religious practices and beliefs that emerged in the second half of the twentieth century. It is generally considered a new religious movement, even if it is inspired by ancient beliefs. It includes different traditions, such as Wicca, Druidry, Heathenry, and Neo-Shamanism. A common characteristic of these traditions is the belief in magic_-sometimes spelled "magick" - and in the interconnectedness between natural and human worlds (Harwood 2007). This means that practitioners, who may selfidentify as "witches," often believe in the power of employing nature's energies to change their lives and connecting their existences with the universe. Because it is highly heterogeneous, it is difficult to find a comprehensive definition of Neo-Paganism and correctly estimate the number of practitioners, which is nonetheless believed to be growing in Europe and the US (Saunders 2013). Gregory Price Grieve (1995) proposes five broad characteristics that apply to most of Neo-Paganism. The first two characteristics are non-Abrahamism and polytheism, expressed by the belief in pantheons, such as Norse or Greek, that precede Judeo-ChristianIslamic traditions. The third characteristic is a reverence for the Earth, exemplified by attention to ecology and an idealized idea of nature. The fourth characteristic is feminism, which can be found in the worship, or at least veneration or honouring, of the feminine principle symbolized by the Goddess. Lastly, Neo-Paganism privileges ritual over beliefs, which results in the creation of spaces and communities of practice.

These characteristics make Neo-Paganism a compelling case study to understand materiality and authority in digital venues. The importance accorded to rituals and nature often results in embodied and material practices (Rountree 2012). For example, Neo-Pagans often worship at places that have for them a historical meaning and a religious value. This is the case with Stonehenge and Medway Megalithis, heritage sites in England whose stones are attributed religious agency and sacred narratives by many Neo-Pagans (Blain and Wallis 2004; White 2016). Some Neo-Pagan practitioners organize travel to what they consider as religiously charged places, such as temples in Greece, to celebrate ancient myths (Bittarello 2006). These connections to places and objects, including ritual tools, exemplify the importance of material culture in Neo-Paganism.

The polytheistic character of Neo-Paganism allows practitioners to honour objects and places from a variety of traditions, sometimes simultaneously. In an exploratory study conducted in Colorado, US, I interviewed five Neo-Pagan practitioners. Each of them explained following a god or a goddess that suited their spiritual needs, greatly personalizing their practice while being part of the same Neo-Pagan community. The personalization of religious beliefs and the worshipping of objects and places from different traditions result in an innovative understanding of authority (Hope and Jones 2006). For example, some Neo-Pagans 
choose to be 'solitary practitioners,' meaning that they are not part of a religious community and perform rituals without the guidance of a religious leader or in the company of a likeminded group. This may connote Neo-Paganism as a religious movement that refuses traditional authority structures and finds alternative forms of legitimation (Rinallo, Maclaran, and Stevens 2016). However, Neo-Paganism does not completely reject religious authority. In Wicca, the biggest tradition within Neo-Paganism, there are priests and priestesses whose authority is generally sanctioned by a formal initiation, and who lead practice groups called "covens" (Hume 1998). Authors such as Scott Cunningham and Gerald Gardner, considered by many the founders of Wicca, published books that many practitioners use as source of authority and guidance. Therefore, authority in Neo-Paganism is often fluid, involves ritual practices, and includes various textual and material sources.

Many Neo-Pagans employ the Internet to find sources of authority and talk about their practices and beliefs. Among the early adopters of the Internet already in the 1990s, Neo-Pagans use websites and discussion boards to get in touch with other practitioners and acquire expertise (Krüger 2005). While not all Neo-Pagans use the Internet to discuss religion, many do so to address the social stigma they experience as individuals and as a community. In certain contexts, indeed, believers may refrain from openly self-identifying as Neo-Pagans and cannot find a group with whom to practice. In addition, solitary practitioners are sometimes stigmatized even within Neo-Pagan communities. Many of them use digital spaces to discuss authority and practices, in some cases even performing rituals online through chats or communication software. As Adam Possamai and Bryan Turner (2012) write, many Neo-Pagans go online to look for alternative sources of authority but often end up reproducing the same structures of offline covens or groups. From this perspective, the Internet does not necessarily disrupt traditional authority structures, but offers venues to enter into contact with people from different geographical areas and various traditions, thus fostering instances of intra- and inter-religious contact.

Neo-Paganism, therefore, is characterized by the veneration of natural places and objects and an extensive use of the Internet. This may appear as a contradiction, if digital technologies are considered the antithesis of the natural world. Grieve (1995) explains that a nature-based religion such as Neo-Paganism can make sense of technology by creating an "imagined community." Referencing the work of Benedict Anderson, Grieve considers that online Neo-Pagan communities are the product of an imaginative effort. Similarly, Stephen O'Leary argues that Neo-Pagans consider the Internet as a "theatre of the imagination" $(1996,797)$ and Arthur Cowan describes Internet-based rituals as taking place in the "imagination of participants" (Cowan 2005, 138). According to these scholars, it is through imagination that Neo-Pagans combine nature-based practices with the use of the Internet. While imagination is an important part of Neo-Pagan digital practices, I would argue that it also needs to be connected to material practices. Imagination, indeed, does not exclude sensorial experiences, but rather helps people to experience the supernatural as real through embodied practices which are connected to the practice of religion (Luhrmann 2012).

In an exploratory study about space creation in digital Neo-Paganism, I have analyzed how Neo-Pagans tend to embed materiality in Internet-based practices without seeing a discrepancy between physicality and technology. For example, I interviewed a practitioner who leads online rituals and is therefore considered by many as an authority figure. This person explained that practitioners are required to employ material aids when performing online rituals (personal communication, 17 September 2016). They usually display candles, music, incense, 
and food in the room while they communicate via computer with the priest or priestess and other participants. The important part of the ritual is mental visualization, but material objects help practitioners-especially those who are beginners-to imagine a physical presence that risks being lost in computer-mediated communications. This shows how Neo-Paganism embeds both materiality and technology in the discussion and imagination of authority online, and creates spaces of practice between virtual and physical dimensions. This article explores these characteristics by analyzing the forum of the website The Celtic Connection, a venue where Neo-Pagans can embed materiality in online discussions of authority.

\section{The Celtic Connection: Analysis of a Neo-Pagan Forum}

The previous section described Neo-Pagans as holding a fluid notion of authority, and often including in their practices both material objects and digital venues. Because Neo-Paganism is highly heterogeneous, it is challenging to find a representative case study that can account for all Neo-Pagan traditions. The website The Celtic Connection (www.wicca.com) can give some insights into how Neo-Pagans discuss materiality and authority online because-as written on its homepage-it is "one of the oldest and largest Wicca, Witchcraft and Pagan sites on the Internet" (retrieved on 12 July 2018). It was established in 1997 and is divided into many sections, including a forum that numbered 2311 members in October 2018. It is based in the US but puts practitioners from all over the world in contact, provided that they speak English, the language of the website. Considering that Neo-Paganism is a small (especially compared with so-called world religions) and largely non-institutionalized religious movement, The Celtic Connection can be regarded as a large and long-lasting online community.

The Celtic Connection was founded by a woman who goes by the name of Kardia Zoe and her late husband Herne, as explained on www.wicca.com. The website includes several pages that discuss various aspects of Neo-Paganism, such as Meditation, Pagan Holidays, Divination, Candle Magic, and Animal Guides. It also provides a link to a Wicca online store that sells books, supplies for building altars, and other Neo-Pagan objects. The Celtic Connection has a blog, but it seems that most of the interactions occur in the forum. The forum users employ nicknames that are designed to protect their anonymity, and which I mention in my analysis. The forum is moderated by people who are referred to as "Council Elders" and is divided in seven sections: two of them are dedicated to newbies for introductions and questions, while the other five include discussions about Wicca and Neo-Paganism, comparative beliefs and practices, Earth-based paths (Druids, Shamanisms and other traditions), Deities, and Holidays. The Celtic Connection mainly aims at people practicing Wicca but, as the different forums' sections exemplify, it also puts in contact people from other Neo-Pagan traditions.

While social networks and other Internet platforms partially replaced them in the last decade, forums can still provide compelling information about digital religion. The Celtic Connection forum, for example, has publicly collected discussions from 2010 and is still active. Posts usually contain long reflections or questions, can embed pictures and links, and sometimes attract hundreds of comments. They are written in an informal style reminiscent of face-to-face conversations. By analyzing forums, it is possible to plunge into discussions and follow their developments. With this in mind, I familiarized myself with The Celtic Connection forum by extensively reading its posts, focusing on those discussing authority and materiality. Because the users post anonymously and there are no references to their identities on the forum, I will mention their usernames in this article. Inspired by Critical Discourse Analysis 
(CDA), I performed a textual analysis (Wodak and Bush 2004) of these posts to explore the forum's dominant narrative patterns. CDA is an approach that considers texts as illustrative of sociocultural practices and social discourses. In particular, it looks at the developments of discourses as pointing to hegemonic and non-hegemonic social elements (Fairclough 2013). In case of a minority religion such as Neo-Paganism, CDA illustrates the tensions between what is perceived as mainstream and non-mainstream religiosity. Future works may explore the online interactions of Neo-Pagans from a quantitative perspective, or perform a network analysis of their exchanges, but in this case, I was interested in conducting an in-depth study that could provide qualitative examples of Internet exchanges. The following two sections explore narratives about authority and materiality in The Celtic Connection forum.

\section{Authority in The Celtic Connection}

The Celtic Connection is a website where users often discuss their practices and beliefs with other Neo-Pagans. Because Neo-Paganism is a heterogeneous religion that allows a great degree of personalization, believers tend to put together, in a creative and syncretic fashion, practices and beliefs from various religious traditions. This attitude is exemplified by the personal story of The Celtic Connection's founder Kardia Zoe, who describes her experience as follows:

As for my personal beliefs and goals, my spiritual background is in Christianity. However, I do not blindly accept certain doctrine taught in many of today's Churches. (...) For the past twenty years I have journeyed with my inner-spirit through mounds of books and manuscripts. I explored everything from Christianity and the Dead Sea scrolls, to Gnosis teachings in the Egyptian Nag Hammadi Library. I started seeing a lot of common ground between the EARLY Christian teachings and many other ancient religions, so I began to do further research into the teachings of Druids, Wiccans, Shamans and any nature based religion I found. I was eventually drawn to the ancient Essene writings. It became clear to me that the Essenes were the very same group we now refer to as the first Christians, and early manuscripts tell us they were a community whose lives were closely bound to nature. A great deal of their scriptures focused on our connection with Mother Earth. What I found most interesting, was that for them, their connection with mother nature, or our Earthly Mother as they called her, was directly linked to their connection with God. This meant that at one time, Christians actually respected and followed the feminine aspect of the Divine too! (The Celtic Connection homepage, retrieved on 11 October $2018^{1}$ )

The quote shows how Kardia Zoe does not reject Christianity, the religion she was raised in, but tries to make sense of her spiritual needs against a Christian background. In so doing, Kardia Zoe creates a type of belief based on religious contacts by combining what she identifies as early Christianity with the worship of Mother Earth and the feminine principle. Being the founder of the website, Kardia Zoe is likely an inspiration for many people that visit The Celtic Connection, and an informal authority that shows how Neo-Pagans can personalize and negotiate their religiosity.

The experience of Kardia Zoe is not unique. The Celtic Connection's members, who often

1 This and all following quotes from The Celtic Connection are reprinted in their original form and have not been edited for spelling or grammar. 
discuss their religious beliefs in the "introduction" section of the forum, usually come from predominantly Christian countries in Europe or North America. This is probably the reason why Christianity seems to remain an interpretative framework and a point of comparison for many of them. For example, a user that goes by the nickname "Callisto" writes, in a post titled "Worshipping across Pantheons":

I'm working through how I think about the gods, how to approach them, who they are. I've loved the Greek pantheon since I was a child and identify with several of the Olympians as spiritual beings. But I'm also drawn to the Norse gods and that worldview. I can't imagine it truly matters in the scheme of things, but it feels slightly odd in some ways to worship different sets of gods. Maybe this is just a holdover from my Catholic upbringing that demands loyalty to one alone. (The Celtic Connection forum, 14 October 2013)

While Kardia Zoe makes sense of her Christian upbringing from a Neo-Pagan perspective, the user Callisto seems to find it problematic to reject some aspects of Catholicism, such as monotheism. The post received some answers from forum members, who share their own experiences in worshipping different gods and describe revelatory dreams or visions. These answers connote gods as archetypes that can be represented across pantheons and point to a transcendent dimension, but also sometimes as embodied and material entities that can appear in dreams and interact with practitioners. Some users advise Callisto to do research about the gods' characteristics and offer suggestions on how to worship gods from different pantheons.

Answers to Callisto's question exemplify a type of informal authority often articulated in the forum. As believers decide to personalize their practice by following different religious traditions, they often rely on self-determination, a type of 'authority of the self' or 'inner authority.' By so doing, practitioners employ their own experiences and feelings to determine what is an acceptable and suitable practice or belief. As the case of Callisto exemplifies, practitioners may use The Celtic Connection forum to ask questions or receive clarifications, especially when they are new to Neo-Paganism, have misgivings about practices or beliefs, or do not know where to find information. In such cases, other forum members act as informal authorities in suggesting possible answers. Some of these members are Council Elders (website moderators), while others are people who claim to have offline experience and knowledge of Neo-Paganism. They usually do not frame themselves as absolute or exclusive authorities, but as experts in Neo-Paganism. Respecting the inner authority of other practitioners, these informal authorities rarely dictate correct approaches to Neo-Paganism, but usually suggest tactics to find suitable spiritual paths. The forum moderators are also clear in stating that The Celtic Connection does not organize online rituals, something that other websites do, or provide mentoring. When a user asks about the matter, Council Elder "Draconis Rex" writes:

I'm afraid we don't really do individual mentoring here (...), but we all serve that purpose together. Take all the instruction, information and guidance you need from what you see here, any questions can be answered, but remember to search for the answer first. Chances are the answers are there already. (The Celtic Connection forum, 30 December 2013)

This quote suggests that The Celtic Connection can function as a space of authority that gathers the collective knowledge of many practitioners. From this perspective, authority is 
framed as knowledge and information sharing from more experienced practitioners to the other users. Council Elders, indeed, often invite new users to read through past forum posts to gain knowledge of Neo-Paganism, connoting the forum itself as a textual source of authority. Many posts also encourage practitioners to learn the basic tenants of Wicca from other textual sources, such as books by Scott Cunningham and Gerald Gardner, some of which are listed in four pinned posts in the "Wicca Q and A" section of the forum. This type of collective and text-based knowledge shows how Neo-Pagans often hold a non-traditional view of authority but do not reject authority altogether.

Authority in The Celtic Connection often emerges from a network of relations and actors. As practitioners put in contact elements from different traditions, they also negotiate their attitude towards gods and pantheons. They discuss practices and beliefs with other forum members, who often act as informal authorities in answering religion-related questions and in discussing offline practices, objects, and religious spaces. These informal authorities also recognize the need of finding mentors offline and consulting other texts. This type of authority is networked because it is based on interpersonal contacts, constantly negotiated and discussed, and not fixed in time. Discussions and displays of authority in the forum often refer to practices that occur in the physical dimension and embed material forms in different ways.

\section{Materiality in The Celtic Connection}

The Celtic Connection is a venue where users directly or indirectly discuss various authority sources. They do so in digital spaces, but they often refer to embodied and material practices happening in physical spaces. For example, many users ask information about rituals, but the performance of the ritual remains an offline experience. Similarly, The Celtic Connection has an online shop where practitioners can find books and other material objects that are advertised online but are aimed at offline religious practices. Therefore, even if The Celtic Connection is a virtual venue, it has a strong material dimension.

The forum displays and negotiates materiality in various ways. While the Internet limits the possibility of sensorial experiences, there are some strategies that forum users employ to enhance existing characteristics of digital spaces. These strategies are often based on visual elements, which people can easily embed in posts. For instance, the user "Alyceavary" writes a post asking for Wicca-related creation stories for children (The Celtic Connection forum, 12 March 2012). The first response, written by a user named "Dark Magus," appears as a long blank post. However, by highlighting it with the computer mouse, the post reveals a creation story written by Wicca author Silver RavenWolf. This simple strategy, achieved by writing the text in the same color of the background, gives the impression that the story magically appears, in what might be a metaphor of the world coming into being. In this case, the user not only acts as informal authority in providing a source for Alyceavary's question but also employs a visual strategy to enhance the reading experience.

Some discussions about material objects involve pictures. This is the case in a post titled "Making my first wand," written by a user who goes by the name of "Spiritwalker." The user describes the experience of making a wand as follows:

So, I've begun making my first wand, its a work In progress. Im making it from the branch of a tree (which I believe is a nispero or mango tree, I played under it in my childhood) that my grandfather cut off due to it getting to close to powerlines. (...) 
Any suggestions? (Patterns, carvings,stones, etc.) (The Celtic Connection forum, 24

August 2013)

In Neo-Paganism, people use wands during rituals to cast spells and enter in communication with transcendent beings. In this post, the user focuses on the material aspects of the wand: the type of wood, the aesthetic patterns, and other visual details. In the post there is also a picture of a partially carved wooden branch with a small knife and some stones. In the corner of the picture there is a cat. The picture probably aims at better describing the wand to other users, according great attention to material details. Other users comment on the post by explaining some of the technical characteristics a wand should have. For example, the user "Oldghost" writes:

The length should be from the tip of you middle finger the to inside of you elbow. What you use for a stone or crystal or stone will depend on what you are doing . Different woods have different properties in magic as well as the stones or crystals you place in them . For your mango or nispero tree you will have to do some research , unless someone here has used them and can help you. (idem)

With this answer, Oldghost acts as an informal authority in providing information about wands and calls for the expertise of other users to assess the characteristics of wood types. The answer suggests that making a wand goes beyond purely aesthetic criteria because the properties embedded in its materiality have an impact on the religious experience.

Some posts include descriptions and pictures of religiously charged spaces. For example, the Council Elder Draconis Rex, in a post titled "Stonehenge," asks: "What significance does Stonehenge hold for you in your path? (...) Would you consider a pilgrimage at some point? would you merely visit in passing?" (The Celtic Connection forum, 28 July 2013). The post attracts answers that describe visits to Stonehenge, including the feelings of touching the stones or the sounds heard in the site. Post author Draconis Rex also comments by giving additional information about Stonehenge:

There is evidence that shows that Stonehenge was actually in use 4000 years earlier than when the stones were constructed. It was revealed that posts were erected in a crescent, the post holes are in evidence and there is organic material revealed to be wood. The "Sarsen" stones range from 7 tons to 45 tons, and the "bluestones" that mark the perimeter weigh in between 2 and 4 tons each. (idem)

In providing this detailed and vivid description of Stonehenge, which includes practical and material details, Draconis Rex may be trying to arouse the curiosity of other users by showing expertise about the venue. In a subsequent comment, Draconis Rex posts pictures of Stonehenge, which probably aims at giving a more realistic impression of the site. Following Draconis Rex's comment, other users shared images of the site. Some users never visited Stonehenge but contribute to the discussion by posting pictures found on Google. Visual elements combined with descriptions of offline materiality help to make the imagination of a religious place more realistic. From this perspective, the forum functions as a digital space of discussion where users can virtually experience physical and material spaces.

Therefore, The Celtic Connection forum is a venue where some Neo-Pagans look for informal authorities that can help their religious practice. Forum exchanges can embed materiality in various ways. For example, they discuss objects and spaces that are relevant not only on an 
aesthetic level but also for the religious experience, because their intrinsic characteristics can affect the way religion is perceived and practiced. In addition, they employ the possibilities of the Internet, such as picture sharing, to help the imagination of these objects and places. This confirms the importance of materiality in Neo-Paganism and connotes the Internet as a space of networked exchanges that points to and embeds offline materiality. It is for this reason that the analysis of digital spaces such as The Celtic Connection can add nuances to the study of online authority and materiality.

\section{Discussion and Conclusion}

The article discussed some material aspects of digital religion by way of the example of the Neo-Pagan forum The Celtic Connection. The analysis of the forum suggests that there are various strategies to negotiate formal and informal authority in material and networked ways. Through this case study, I would argue that a focus on material culture can be a starting point to think about religion, media, and authority in new ways, because it directs attention to practices that occur outside traditional institutions and between online and offline venues. Digital religion, indeed, is networked and relies on interpersonal exchanges, and creates instances of contact that tend to be fluid and rapidly evolving in time. Material culture and digital culture are not at odds with each other but can be entangled in creating narratives about authority that point to a variety of material objects. In other words, the material world remains a constant point of reference also for people who discuss their religious practices online. The case study of The Celtic Connection compels some concluding reflections about religious authority and media from a material perspective.

Digital media embed many articulations of religious authority. Attention to digital and material practices can help to understand different aspects of religious authority because it focuses on interpersonal exchanges and material displays. Authority exists in digital venues on different interconnected levels: textual sources described and embedded in web pages, experts that offer suggestions on forums and blogs, discussions about objects that exist in offline spaces. For example, in The Celtic Connection forum, the moderators-Council Elders-discuss NeoPaganism by giving advice about books, material objects, and offline rituals. In addition, the Internet multiplies the occasions for intra- and inter-religious contact: in digital spaces, people can gain new understandings of authority by entering into conversation with groups from other parts of the world (e.g. describing a place such as Stonehenge and discussing its meaning for different Neo-Pagan groups) and getting to know different traditions (e.g. combining Christianity and Neo-Paganism). From this perspective, authority is not only networked, in the sense of Campbell (2012a), but also frequently mediated, or "hypermediated" (Evolvi 2018). This means that authority can exist in a variety of settings that are interconnected through digital technology and involve many actors and actions.

This suggests that authority in digital venues includes some peculiar characteristics. First, it is conditioned by the current proliferation of media technologies, which Nick Couldry defines as "media supersaturation" (2012). While religious institutions can decide to trust the Internet to different degrees, they cannot ignore that digital technologies have changed some interpersonal communication dynamics. As a result, authority becomes inevitably dependent on the logics of fast and interconnected media platforms, as happens in The Celtic Connection forum. Second, it exists both as human authority and as authority of the Internet. As exemplified by The Celtic Connection, users can write forum posts to gain advice from other believers, 
but also consider the Internet itself-almost as a personified entity-as a source of authority. Some Neo-Pagan users may decide for themselves, relying on their "inner authority," which practices and beliefs to follows. At the same time, they may also read long forum threads as textual sources of information. Third, there are new authority figures that emerge and that need to be analyzed and theorized. For instance, The Celtic Connection's Council Elders and other experienced users might not be considered authorities in the classical sense, but can be understood as informal charismatic authorities, to draw from Max Weber's terminology. Their expertise comes from offline knowledge of Neo-Paganism, but also from the network of social interactions they create on the forum, their ability to navigate media logics and communicate effectively with other users, and the understanding of different traditions in a situation of religious contact. Therefore, it is necessary to go beyond traditional categories of authority and develop new frameworks that can account for non-traditional forms of authority in digital spaces.

Changes in religious authority also involve material practices that compel reflections on the role of media. Material practices, indeed, include both physical objects and communication technologies (as discussed by Entangled Religions' working paper "Media" 2 ). The Celtic Connection forum offers a venue to describe offline material practices, such as the construction of a wand or a visit to Stonehenge, as well as revelatory dreams where gods are connoted as material and embodied entities. These descriptions can help Neo-Pagans' imagination, as suggested by Grieve (1995) and O'Leary (1996). This type of online experience is different from offline happenings, but it is not disjointed from reality or disconnected from materiality. On the contrary, it arguably points to a different way of experiencing religion that might be real and authentic for some practitioners. The popularity of The Celtic Connection forum suggests that users consider its discussions meaningful and connect them to offline material religious experiences in a tangible and authentic way. Therefore, it is important to analyze the connections between online and offline spaces and consider the Internet as a medium that potentially allows for material and authentic religious experiences, as we are reminded in the work, among others, of Campbell and Lövheim (2011).

Online spaces participate in mediation when they help believers to experience religion by offering venues to describe and negotiate material practices and beliefs. Henry Jenkins defines the circulation of media objects on different platforms as "remediation" (2008). Diffusion of narratives and pictures on The Celtic Connection, such as images of Stonehenge shared and commented upon by multiple users, may be considered a particular type of remediation, or "double mediation." It is, indeed, a mediation that allows symbolic connections to material objects and spaces by enhancing another mediation already occurring in physical venues. For instance, the wand is a medium because people use it as a tool of mediation to experience transcendence during offline rituals, and it is further mediated (or double mediated) through discussions and displays on another medium, the Internet. This perspective compels, on the one hand, the elaboration of a broad definition of media, as articulated in the working paper "Media" on Entangled Religions, that includes all material objects invested with religious meaning. On the other hand, the computer and the Internet need to be considered not simply as communication tools, but material objects that can be embedded in various ways, and in some cases make possible, the religious practice.

Therefore, the Internet has an impact on religion by offering believers venues to get in

2 https://static.ceres.rub.de/media/filer_public/35/0d/350ded7c-8546-4114-9b39-7a6751f58358/er-khk4_media_170728.pdf, retrieved June 3, 2020. 
contact with each other and tools for the religious experience. The diffusion of digital culture does not radically change religion and religious authority because these aspects continue to be connected to material experiences in physical settings, even if in different ways. The understanding of these facets of digital religion can benefit from methodological and theoretical efforts that accord attention to materiality. For example, it is important to recognize the existence of alternative types of authority and consider their role even when they act informally and in non-traditional venues, such as the Internet. Furthermore, the study of virtual spaces needs to take into account the connections with physical spaces (and vice versa) and the material practices connected with digital technologies. By so doing, it is possible to gain a more nuanced understanding of religious practices and authority in digital venues and to explore the importance of materiality for digital religion.

\section{References}

Bittarello, Maria Beatrice. 2006. "Neopagan Pilgrimages in the Age of the Internet: A Life Changing Religious Experience or an Example of Commodification?" Journal of Tourism and Cultural Change 4 (2): 116-35. https://doi.org/10.2167/jtcc054.0.

Blain, Jenny, and Robert J. Wallis. 2004. "Sacred Sites, Contested Rites/ Rights: Contemporary Pagan Engagements with the Past." Journal of Material Culture 9 (3): 237-61. https: //doi.org/10.1177/1359183504046893.

Campbell, Heidi A. 2007. "Who's Got the Power? Religious Authority and the Internet." Journal of Computer-Mediated Communication 12 (3): 1043-62. https://doi.org/10.1111/j.10 83-6101.2007.00362.x.

- 2010. "Religious Authority and the Blogosphere." Journal of Computer-Mediated Communication 15 (2): 251-76. https://doi.org/10.1111/j.1083-6101.2010.01519.x.

. 2012a. "Understanding the Relationship Between Religion Online and Offline in a Networked Society." Journal of the American Academy of Religion 80 (1): 64-93. https: //doi.org/10.1093/jaarel/lfr074.

— ed. 2012b. Digital Religion: Understanding Religious Practice in New Media Worlds. Abingdon, Oxon ; New York: Routledge.

Campbell, Heidi A., and Mia Lövheim. 2011. "Introduction." Information, Communication \& Society 14 (8): 1083-96. https://doi.org/10.1080/1369118X.2011.597416.

Couldry, Nick. 2012. Media, Society, World: Social Theory and Digital Media Practice. Malden, MA: Polity.

Cowan, Douglas E. 2005. "Online U-Topia: Cyberspace and the Mythology of Placelessness." Journal for the Scientific Study of Religion 44 (3): 257-63. https://doi.org/10.1111/j.14 68-5906.2005.00284.x.

Evolvi, Giulia. 2018. Blogging My Religion: Secular, Muslim, and Catholic Media Spaces in Europe. New York: Routledge.

Fairclough, Norman. 2013. Critical Discourse Analysis: The Critical Study of Language. London: Routledge.

Grieve, Gregory Price. 1995. "Imagining a Virtual Religious Community: Neo-Pagans and the Internet." Chicago Anthropology Exchange 7: 98-132.

Harwood, Brandon J. 2007. "Beyond Poetry and Magick: The Core Elements of Wiccan Morality." Journal of Contemporary Religion 22 (3): 375-90. https://doi.org/10.1080/135379 00701637528. 
Hoover, Stewart M., ed. 2016. The Media and Religious Authority. University Park, Pennsylvania: Penn State University Press.

Hope, Tom, and Ieuan Jones. 2006. "Locating Contemporary British Paganism as Late Modern Culture." Journal of Contemporary Religion 21 (3): 341-54. https://doi.org/10.1080/13 537900600926097.

Horsfield, Peter. 2013. "The Ecology of Writing and the Shaping of Early Christianity." In Religion Across Media: From Early Antiquity to Late Modernity, edited by Knut Lundby. New York: Peter Lang.

— 2016. "The Media and Religious Authority from Ancient to Modern." In The Media and Religious Authority, edited by Stewart M. Hoover. Pennsylvania: Penn State University Press.

Houtman, Dick, and Birgit Meyer. 2012. Things: Religion and the Question of Materiality. New York: Future of the Religious Past.

Hume, Lynne. 1998. "Creating Sacred Space: Outer Expressions of Inner Worlds in Modern Wicca." Journal of Contemporary Religion 13 (3): 309-19. https://doi.org/10.1080/1353 7909808580838.

Hutchings, Tim, and Joanne McKenzie. 2016. Materiality and the Study of Religion: The Stuff of the Sacred. New York: Routledge.

Jenkins, Henry. 2008. Convergence Culture: Where Old and New Media Collide. Revised edition. New York, NY: NYU Press.

Krüger, Oliver. 2005. "Discovering the Invisible Internet : Methodological Aspects of Searching Religion on the Internet." Edited by Oliver Krüger. Online - Heidelberg Journal of Religions on the Internet: Volume 01.1 Special Issue on Theory and Methodology. https: //doi.org/https://doi.org/10.11588/heidok.00005828.

Luhrmann, T. M. 2012. "Touching the Divine: Recent Research on Neo-Paganism and NeoShamanism." Reviews in Anthropology 41 (2): 136-50. https://doi.org/10.1080/009381 57.2012.680425.

Metzger, Miriam J., and Andrew J. Flanagin. 2013. "Credibility and Trust of Information in Online Environments: The Use of Cognitive Heuristics." Journal of Pragmatics 59 (December): 210-20. https://doi.org/10.1016/j.pragma.2013.07.012.

Meyer, Birgit. 2005. "Religious Sensations: Why Media, Aesthetics and Power Matter in the Study of Contemporary Religion." Inaugural Lecture, Inaugural Lecture.

- ed. 2010. Aesthetic Formations: Media, Religion, and the Senses. Palgrave Macmillan.

—. 2020. "Religion as Mediation." Entangled Religions 11 (3). https://doi.org/10.13154 /er.11.2020.8444.

Morgan, David. 2016. "Material Analysis and the Study of Religion." In, edited by Tim Hutchings and Joanne McKenzie. New York: Theology and Religion in Interdisciplinary Perspective Series in Association With the Bsa Sociology of Religion Study Group.

Narbona, Juan. 2016. "Digital Leadership, Twitter and Pope Francis." Church, Communication and Culture 1 (1): 90-109. https://doi.org/10.1080/23753234.2016.1181307.

O'Leary, Stephen D. 1996. "Cyberspace as Sacred Space: Communicating Religion on Computer Networks." Journal of the American Academy of Religion 64 (4): 781-808. http: //www.jstor.org/stable/1465622.

Possamai, Adam, and Bryan S. Turner. 2012. "Authority and Liquid Religion in Cyber-Space: The New Territories of Religious Communication." International Social Science Journal 63 (209-210): 197-206. https://doi.org/10.1111/issj.12021. 
Rinallo, Diego, Pauline Maclaran, and Lorna Stevens. 2016. "A Mixed Blessing: MarketMediated Religious Authority in Neopaganism." Journal of Macromarketing 36 (4): 42542. https://doi.org/10.1177/0276146716655780.

Rountree, Kathryn. 2012. "Neo-Paganism, Animism, and Kinship with Nature." Journal of Contemporary Religion 27 (2): 305-20. https://doi.org/10.1080/13537903.2012.6757 46.

Saunders, Robert A. 2013. "Pagan Places: Towards a Religiogeography of Neopaganism." Progress in Human Geography 37 (6): 786-810. https://doi.org/10.1177/0309132512 473868.

Staehle, Hanna. 2018. "Seeking New Language: Patriarch Kirill's Media Strategy." Religion, State and Society 46 (4): 1-18. https://doi.org/10.1080/09637494.2018.1510213.

— 2020. "Russian Orthodox Clergy and Laity Challenging Institutional Religious Authority Online: The Case of Ahilla.ru." Entangled Religions 11 (3). https://doi.org/10.13154 /er.11.2020.8445.

Weber, Max. (1921-1922) 2013. Economy and Society. Edited by Guenther Roth and Claus Wittich. Berkeley: University of California Press.

White, Ethan Doyle. 2016. "Old Stones, New Rites: Contemporary Pagan Interactions with the Medway Megaliths." Material Religion 12 (3): 346-72. https://doi.org/10.1080/17 432200.2016.1192152.

Wodak, Ruth, and Brigitta Bush. 2004. "Approaches to Media Texts." In The Sage Handbook of Media Studies, edited by John D. H. Downing, Ellen Wartella, Denis McQuail, and Philip Schlesinger. Thousand Oaks: Sage. 